Article

\title{
Antioxidant Effects, Antiproliferative Effects, and Molecular Docking of Clinacanthus nutans Leaf Extracts
}

\author{
Noor Zafirah Ismail ${ }^{D}$, Zaleha Md Toha, Musthahimah Muhamad, \\ Nik Nur Syazni Nik Mohamed Kamal D, Nur Nadhirah Mohamad Zain and Hasni Arsad *(D) \\ Advanced Medical and Dental Institute, Universiti Sains Malaysia, Bertam, \\ Kepala Batas 13200, Penang, Malaysia; piecesnzi@gmail.com (N.Z.I.); Zaleha.mdtoha@usm.my (Z.M.T.); \\ musthahimahmuhamad@gmail.com (M.M.); niksyazni@usm.my (N.N.S.N.M.K.); \\ nurnadhirah@usm.my (N.N.M.Z.) \\ * Correspondence: hasniarsad@usm.my; Tel.: +60-4562-2415
}

Academic Editors: Luisa Tesoriere and Alessandro Attanzio

Received: 5 February 2020; Accepted: 13 March 2020; Published: 29 April 2020

\begin{abstract}
Clinacanthus nutans is a well-known herb that has been used as an alternative and therapeutic medicine, however more selective $C$. nutans extracts are needed. In this study, leaves were extracted with $80 \%$ methanol and further fractionated with $n$-hexane, dichloromethane, chloroform, n-butanol, and aqueous residue. Subsequently, the total phenolic content (TPC), total flavonoid content (TFC), antioxidant scavenging activity, and antiproliferative effects on breast cancer (Michigan Cancer Foundation-7 [MCF7]) and normal breast (Michigan Cancer Foundation-10A [MCF 10A]) cells of the extracts were measured. Additionally, molecular docking simulation of the major compounds from $C$. nutans extracts was conducted. The aqueous residue had the highest TPC and TFC, whereas the crude extract had the highest scavenging activity. Among the extracts, dichloromethane extract (CN-Dcm) was selected as it had the highest selectivity index (SI) (1.48). Then, the chosen extract (CN-Dcm) was proceed for further analysis. The compounds from CN-Dcm were identified using gas chromatography-mass spectrometry (GC-MS). The major compounds from CN-Dcm were further investigated through molecular docking studies. Palmitic acid and linolenyl alcohol were the compounds found in the CN-Dcm extract that exhibited the highest binding affinities with p53-binding protein Mdm-2. These results highlight the potential of $C$. nutans as a source of anticancer activities.
\end{abstract}

Keywords: Clinacanthus nutans; antiproliferative effect; antioxidant; GC-MS; molecular docking

\section{Introduction}

Cancer is a major health problem and the most devastating life-threatening disease worldwide [1] It is characterized by dysregulated cell growth, cell division, and cell death, and by the rapid proliferation of abnormal cells [2]. Global Cancer Incidence, Mortality and Prevalence (GLOBOCAN) reported that from 2012, 1.67 million new breast cancer cases occurred worldwide [3], and breast cancer is the most common cancer among Malaysian women [4]. Although the majority of breast cancer patients are female, a small number of men also suffer from breast cancer [4]. To date, chemotherapy is the first therapeutic strategy to fight cancers, despite the strong side effects. [5]. Natural products can assist the action of chemotherapy but cannot replace them yet. The demand for natural products, especially from medicinal plants, has increased because chemotherapeutic drugs are expensive, lead to morbidity, and have many side effects [6].

Clinacanthus nutans is a medicinal plant that has many medicinal properties, including treating lesions generated by the herpes-simplex virus, antiinflammatory, anticancer, antibacterial, and 
antivenom activities [7]. C. nutans is found in Malaysia, Vietnam, Indonesia, Thailand, and China [8,9], and occurs in most habitats [10]. Many studies carried out abroad have proven the effectiveness of $C$. nutans as an anticancer agent on several types of cancer cells. However, there is still lack of information on the effectiveness of $C$. nutans fraction solvent from various degrees of polarity on breast cancer cells. Michigan Cancer Foundation-7 (MCF7) is the favored cell line, mainly because of its sensitivity to the hormone estrogen, as it possesses estrogen receptors [11]. MCF7 is an ideal model for an in vitro hormone response study because it works well when incorporated into xenograft models, such as rabbit or mice models for in vivo tumorigenic experiments in the presence of estrogen, compared to breast cancer cell lines, such as MDA-MB-453 and SKBR3 cells, which do not have significant in vivo tumorigenic potential [12], or MDA-MB-231, which has poor in vivo metastatic effects [13]. Additionally, some MCF7 in vitro therapeutic response research studies have been translated to successful clinical trials and subsequent development of anticancer drugs [14].

Therefore, this study would be beneficial to further explore the antiproliferative effect of $C$. nutans extract on MCF7 cells. Additionally, many C. nutans studies did not evaluate the effect of C. nutans extracts on normal breast cancer cells. The use of normal cells ensures that the $C$. nutans extracts are not toxic to healthy cells. Thus, the goal of this study was to test the ability of different extracts of $C$. nutans to inhibit breast cancer cell proliferation. We measured the total phenolic content (TPC), total flavonoid content (TFC), and antioxidant scavenging activity of the $C$. nutans crude extract and its fractions using 2,2-diphenyl-1-picrylhydrazyl (DPPH) and 2,2'-azino-bis(3-ethylbenzothiazoline-6-sulfonic acid (ABTS) assays. We also evaluated the effects of the extracts on the cell growth of estrogen responsive breast cancer (MCF7) and normal breast (MCF 10A) cells, identified compounds from selected extracts using gas chromatography-mass spectrometry (GC-MS), and investigated the major compounds using molecular docking studies to evaluate their binding affinities with targeted apoptosis proteins.

\section{Results and Discussion}

\subsection{Extraction Yield}

Extraction of C. nutans leaves was performed using $80 \%$ methanol. The crude methanolic extract was further fractionated sequentially with different solvents (hexane, dichloromethane, chloroform, $\mathrm{n}$-butanol, and aqueous residue). The effectiveness of plant extraction depends on the extraction method and on the solvent used, as solvents with different polarities have a significant effect on the chemical contents of the extracts. Thus, it is important to identify the optimal solvents for extraction of antioxidant compounds from medicinal plants [15]. Water was employed for the extraction because of its universal solubility of polar compounds, while methanol was chosen due to its ability to extract lower molecular weight polyphenols [16] and its tendency to yield relevant antioxidant and cytotoxic compounds from C. nutans [17]. Part of the crude methanolic extract was fractionated using different solvents to concentrate and enhance the purity of active compounds and remove unwanted interferences [16]. Table 1 shows the percentage yield of crude and fraction extracts of C. nutans leaves. The yield of the crude methanolic extract of $C$. nutans leaves (CN-Crd) was $6.85 \%$, and the yield of the fractions varied from $2.18 \%$ to $37.71 \%$ in the following ascending order: aqueous residue $(\mathrm{CN}-\mathrm{Aqu})>$ $n$-butanol $(\mathrm{CN}-\mathrm{But})>$ dichloromethane $(\mathrm{CN}-\mathrm{Dcm})>n$-hexane $(\mathrm{CN}-\mathrm{Hex})>$ chloroform $(\mathrm{CN}-\mathrm{Chl})$. The percentage yields were significantly different $(p<0.05)$. 
Table 1. Percentage yield of crude and fraction extracts of $C$. nutans leaves.

\begin{tabular}{cc}
\hline Type of Extracts & Percentage Yield (\%) \\
\hline CN-Crd & $6.85 \pm 0.15^{\mathrm{a}}$ \\
CN-Hex & $4.10 \pm 0.08^{\mathrm{b}}$ \\
CN-Dcm & $13.73 \pm 0.05^{\mathrm{c}}$ \\
CN-Chl & $2.18 \pm 0.24^{\mathrm{d}}$ \\
CN-But & $20.16 \pm 0.34^{\mathrm{e}}$ \\
CN-Aqu & $37.71 \pm 0.09^{\mathrm{f}}$
\end{tabular}

Effect of different solvents on extraction yield. The percentage yield shows significantly different $(p<0.05)$. Different lowercase characters represent significant difference $(p<0.05)$. CN-Crd, crude methanolic extract; CN-Hex, hexane fraction extract; $\mathrm{CN}-\mathrm{Dcm}$, dichloromethane fraction extract; $\mathrm{CN}-\mathrm{Chl}$, chloroform fraction extract; $\mathrm{CN}$-But, $n$-butanol fraction extract; $\mathrm{CN}-\mathrm{Aqu}$, aqueous residue fraction extract.

\subsection{TPC and TFC}

The phenolic and flavonoid contents of the $C$. nutans extracts were measured because they are major contributors to the extract's overall antioxidant activities. Figure 1 shows the TPC and TFC of the C. nutans extracts and fractions. The $\mathrm{CN}$-Aqu fraction extract $(415.76 \mathrm{mg}$ gallic acid equivalent (GAE)/g extract) contained the highest amount of phenolics and the CN-Hex extract $(50.24 \mathrm{mg} \mathrm{GAE} / \mathrm{g}$ extract) contained the least. TPC values in descending order were as follows: CN-Aqu $>$ CN-But $>$ $\mathrm{CN}-\mathrm{Dcm}>\mathrm{CN}-\mathrm{Crd}>\mathrm{CN}-\mathrm{Chl}>\mathrm{CN}-\mathrm{Hex}$. The TPC of the $\mathrm{CN}$-Aqu fraction was higher than other values reported in the literature for C. nutans extracts. For example, Sarega et al. [18] reported that the aqueous extract of $C$. nutans had a phenolic content of $63.77 \pm 7.31 \mathrm{mg} \mathrm{GAE} / \mathrm{g}$ extract. On the other hand, other plants reportedly have higher phenolic contents in the $n$-butanol extract, which agreed with the results of this study (i.e., CN-But had the second highest TPC). For instance, the phenolic content of the $n$-butanol extract of Vernonia blumeoides was $410 \pm 0.8 \mathrm{mg}$ GAE/g extract [19]. In our study, $n$-hexane extract of $C$. nutans had the lowest TPC; similarly, Johari et al. [20] reported that the hexane extract of Pereskia bleo had the lowest total phenolic content of $25.20 \pm 0.01 \mathrm{mg} \mathrm{GAE} / \mathrm{g}$ extract. The results of our analysis showed that TFC was lower than TPC in all extracts. This was not surprising, as flavonoids are subgroups of phenolics that contribute to the overall amounts of phenolics [20].

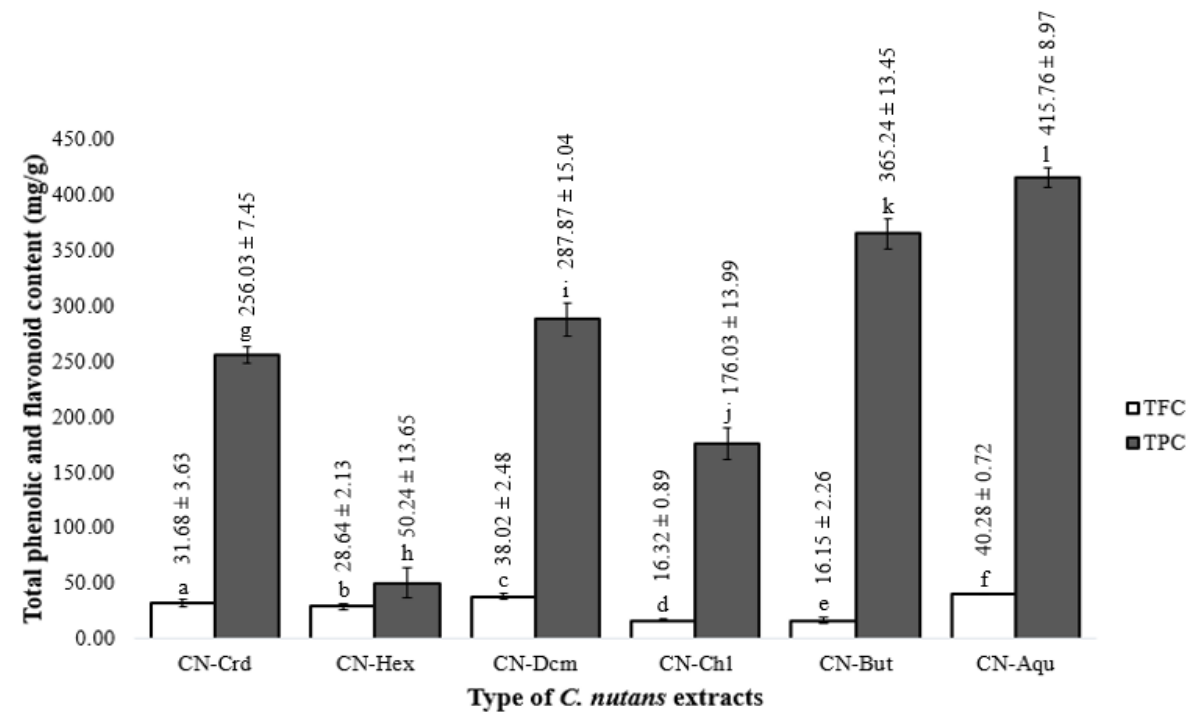

Figure 1. Total phenolic contents (TPC) and total flavonoid contents (TFC) of crude and fraction of C. nutans leaf extracts. A comparison of TPC and TFC in different $C$. nutans extracts; data represent mean $\pm \mathrm{SD}, n=3$. LSD, least significant difference; level of significance: $p<0.05$ using Bonferroni test analysis. Different lowercase characters represent significant difference. 


\subsection{Antioxidant Capacities}

The antioxidant capacities of the $C$. nutans extracts were quantified using 2,2-diphenyl1-picrylhydrazyl (DPPH) and 2,2'-azino-bis(3-ethylbenzothiazoline-6-sulfonic acid (ABTS) assays. The use of at least two methods is recommended to evaluate and compare the antioxidant capacity of a sample [21]. Because they are stable radicals, DPPH and ABTS are widely used to determine the antioxidant activity of plants [22,23]. Table 2 shows the half-maximal effective concentration $\left(\mathrm{EC}_{50}\right)$ of the extracts and fractions of $C$. nutans leaves. The $\mathrm{EC}_{50}$ is the concentration of antioxidant that causes a $50 \%$ decrease in radical absorbance, which is commonly assessed by measuring antioxidant concentration readings [24]. Trolox, which is a well-known natural antioxidant, was used as the standard. The $C$. nutans extracts ranged between 125 and $4000 \mu \mathrm{g} / \mathrm{mL}$. The antioxidant activities measured using the ABTS assay were lower than values determined by the DPPH assay, which is in agreement with results reported by Lachman et al. [25]. Samples with lower $\mathrm{EC}_{50}$ values are considered to have high antioxidant capacity [26]. The $\mathrm{EC}_{50}$ values calculated from the DPPH and ABTS assays for the crude and fraction extracts of C. nutans ranged from 560.50 to $1530.00 \mu \mathrm{g} / \mathrm{mL}$ and from 476.30 to $1024.00 \mu \mathrm{g} / \mathrm{mL}$, respectively. Based on the $\mathrm{EC}_{50}$ value, $\mathrm{CN}-\mathrm{Hex}$ had the lowest antioxidant activity and $\mathrm{CN}-\mathrm{Crd}$ had the highest antioxidant activity. Haron et al. [17] also reported that the crude methanol extract of $C$. nutans leaves showed the highest scavenging effect (DPPH $=$ $21.18 \mathrm{mg}$ Trolox $/ \mathrm{g}$, ABTS $=11.80 \mathrm{mg}$ Trolox $/ \mathrm{g}$ ), while the hexane fraction had the lowest scavenging activity (DPPH $=1.06 \mathrm{mg}$ Trolox/g). However, Alam et al. [27] reported that the crude methanol extract of $C$. nutans leaves had the lowest scavenging activity. These differences in results likely occurred because the plants are largely influenced by environmental conditions, such as temperature, rainfall, water variability, humidity, variations in soil $\mathrm{pH}$, nutrient contents, and exposure to soil microorganisms [28]. Moreover, environmental factors interact with the genetics of the plants, which lead to genetic variations [29] that affect the phytochemical contents.

Table 2. The half-maximal effective concentration $\left(\mathrm{EC}_{50}\right)$ of $C$. nutans crude and fraction extracts for 2,2-diphenyl-1-picrylhydrazyl (DPPH) and 2,2'-azino-bis(3-ethylbenzothiazoline-6-sulfonic acid (ABTS) radical scavenging activities.

\begin{tabular}{ccc}
\hline Type of Extracts & DPPH $(\mu \mathrm{g} / \mathrm{mL})$ & ABTS $(\mu \mathrm{g} / \mathrm{mL})$ \\
\hline CN-Crd & $560.50 \pm 2.45$ & $476.30 \pm 0.74$ \\
CN-Hex & $1530.00 \pm 3.74$ & $1024.00 \pm 4.18$ \\
CN-Dcm & $1039.00 \pm 0.87$ & $937.00 \pm 3.84$ \\
CN-Chl & $796.40 \pm 7.21$ & $602.50 \pm 1.74$ \\
CN-But & $837.10 \pm 3.14$ & $837.40 \pm 9.45$ \\
CN-Aqu & $744.30 \pm 8.45$ & $718.00 \pm 1.84$ \\
Trolox standard & $32.33 \pm 2.47$ & $37.74 \pm 2.15$ \\
\hline
\end{tabular}

Effect of $\mathrm{EC}_{50}$ of $\mathrm{C}$. nutans crude and fraction extracts. The $\mathrm{EC}_{50}$ are significantly different $(p<0.05)$. CN-Crd, crude methanolic extract; $\mathrm{CN}-\mathrm{Hex}$, hexane fraction extract; $\mathrm{CN}-\mathrm{Dcm}$, dichloromethane fraction extract; $\mathrm{CN}-\mathrm{Chl}$, chloroform fraction extract; $\mathrm{CN}-\mathrm{But}, n$-butanol fraction extract; $\mathrm{CN}-\mathrm{Aqu}$, aqueous residue fraction extract.

\subsection{Antiproliferative Assay}

The antiproliferative activity of the extracts was assessed using the sulforhodamine B (SRB) assay. SRB is a fluorescent dye used to quantify the proteins present in cultured cells. The SRB dye binds to the amino acids of cellular proteins and then the dye can be used to estimate the cell viability [30]. Based on the SRB assay, we compared the results of the SRB assay with 3-(4,5-dimethylthiazol-2-yl)-5-(3-carboxymethoxyphenyl)-2-(4-sulfophenyl)-2H-tetrazolium (MTS) and alamar blue assays at $72 \mathrm{~h}$ of exposure (Table S1). The results showed no significant differences between three cytotoxicity assays ( $p>0.05)$, which were in agreement with studies reported by Aslantürk [31] and Vajrabhaya and Korsuwannawong [32]. The 3-(4,5-dimethylthiazol-2-yl)-2,5-diphenyl-2H-tetrazolium bromide (MTT) assay was a commonly used cytotoxicity assay. However, van Tonder et al. [33] describes that the MTT assay was less accurate in detecting changes in cell numbers. They [33] also 
expressed that that SRB assay appears to be more sensitive than MTT assay, which was in line with the studies by Skehan et al. [34] and Vajrabhaya and Korsuwannawong [32], who reported that SRB assay had better linearity with cell number and higher reproducibility. Thus, we choose SRB assay to report the antiproliferative effects of crude and fraction extracts of $C$. nutans.

The antiproliferative activities of the crude and fraction extracts of $C$. nutans leaves were tested on MCF7 and MCF 10A cells to determine their inhibitory effects on cell proliferation. Figure 2 shows the effect of various concentrations of crude and fraction extracts on cell viability of MCF7 and MCF $10 \mathrm{~A}$ cells. Tamoxifen was used as the positive control and its $\mathrm{IC}_{50}$ for MCF7 cells was $3.42 \pm 0.46 \mu \mathrm{g} / \mathrm{mL}$. Tamoxifen also inhibited MCF 10A normal breast cells, with an $\mathrm{IC}_{50}$ value of $1.67 \pm 0.31 \mu \mathrm{g} / \mathrm{mL}$. The CN-Crd extract inhibited $50 \%$ of MCF7 cell growth at $496.50 \pm 0.45 \mu \mathrm{g} / \mathrm{mL}$. This result is in agreement with the observed cytotoxic effect of the crude methanol extract of $C$. nutans leaves on human immortalized myelogenous leukemia (K-562) cells, with $\mathrm{IC}_{50}>100 \mu \mathrm{g} / \mathrm{mL}$ at $72 \mathrm{~h}$ [35]. Our results showed that CN-Crd had a low inhibitory effect on MCF7 cells. Haron et al. [36] also showed that the crude extract had a low inhibitory effect on cervical cancer (HeLa) cells. Based on the antiproliferative activity of MCF10A, the results demonstrated that $\mathrm{CN}-\mathrm{Crd}$ of $C$. nutans leaves inhibited the growth of MCF 10A cells, with an $\mathrm{IC}_{50}$ of $53.15 \pm 0.23 \mu \mathrm{g} / \mathrm{mL}$.

The $\mathrm{CN}$-Crd extract was sequentially fractionated using $n$-hexane, dichloromethane, chloroform, and $n$-butanol, and the antiproliferative effects of these fractions on MCF7 cells were investigated. Fractionation was performed because fractions of crude alcoholic extracts may have high inhibitory effects against cancer cells [36,37]. Adebayo et al. [37] found that the hexane fraction of the crude $80 \%$ ethanolic extract of Moringa oleifera had stronger antiproliferation activity against cancer cells compared to the crude extract. Similarly, hexane, dichloromethane, ethyl acetate, and butanol fractions of the crude methanolic extract of Ziziphus mauritiana bark had high inhibitory effects on MCF7, HeLa, prostate cancer (PC3), and lung cancer (NCI-H460) cells [38].

In our study, the CN-Hex fraction had the greatest inhibitory effects on MCF7 cells, with an $\mathrm{IC}_{50}$ of $50.34 \pm 0.11 \mu \mathrm{g} / \mathrm{mL}$, followed by the CN-Dcm fraction $\left(\mathrm{IC}_{50}=65.95 \pm 0.17 \mu \mathrm{g} / \mathrm{mL}\right), \mathrm{CN}-\mathrm{Chl}\left(\mathrm{IC}_{50}=67.52\right.$ $\pm 0.17 \mu \mathrm{g} / \mathrm{mL}), \mathrm{CN}-B u t\left(\mathrm{IC}_{50}=111.50 \pm 0.20 \mu \mathrm{g} / \mathrm{mL}\right)$, and CN-Aqu $\left(\mathrm{IC}_{50}=398.00 \pm 0.24 \mu \mathrm{g} / \mathrm{mL}\right)$. Wang et al. [39] reported that the $\mathrm{IC}_{50}$ of the hexane fraction of $C$. nutans leaves was $84.77 \pm 3.43 \mu \mathrm{g} / \mathrm{mL}$, which was higher than the $\mathrm{IC}_{50}$ for $\mathrm{CN}-\mathrm{Hex}$; this means that the $\mathrm{CN}-\mathrm{Hex}$ fraction was more toxic than the hexane fraction in Wang et al.'s study [39]. There are no published reports about the antiproliferative effects of the dichloromethane, chloroform, and $n$-butanol fractions of the crude methanolic extract of C. nutans on MCF7 cells. However, the inhibitory effect of the CN-Dcm fraction on the growth of MCF7 cells in our study was comparable to the observed antiproliferative effect of the dichloromethane fraction of $C$. nutans leaves on HeLa cells that was reported by Haron et al. [36]. CN-Dcm was more effective for MCF7 cells because it had a lower $\mathrm{IC}_{50}$. On the other hand, $\mathrm{CN}-\mathrm{Chl}$ inhibited MCF7 cell growth at a lower concentration $(67.52 \pm 0.17 \mu \mathrm{g} / \mathrm{mL})$. There was no inhibition of MCF7 cell growth when the cells were treated with CN-Crd and CN-Aqu extracts at concentrations below $100 \mu \mathrm{g} / \mathrm{mL}$.

The fraction extracts were also tested for their effects on MCF 10A cells (Figure 2b). MCF 10A cells were used to obtain the selective indices (SI) of the extracts. The SI value was calculated as the ratio of the $\mathrm{IC}_{50}$ values of the extracts on MCF 10A cells relative to those in the MCF7 cells. According to Segun et al. [40], an SI value $>1$ one suggests that an extract is less toxic to normal cells compared with cancer cells, thus compounds with high SI values can be assumed to offer potential safer therapy. Table 3 shows the SI values of the crude and fraction extracts of $C$. nutans leaves. In ascending order, the $\mathrm{SI}$ values were as follows: $\mathrm{CN}-\mathrm{Dcm}>\mathrm{CN}-\mathrm{Chl}>\mathrm{CN}-\mathrm{Hex}>\mathrm{CN}-\mathrm{But}>\mathrm{CN}-\mathrm{Aqu}>\mathrm{CN}-\mathrm{Crd}$. CN-Dcm inhibited MCF 10A cell growth, with an $\mathrm{IC}_{50}$ value of $100.20 \pm 2.88 \mu \mathrm{g} / \mathrm{mL}$ and an SI value of 1.48 , which means that this fraction extract was selective. On the other hand, $\mathrm{CN}-\mathrm{Hex}, \mathrm{CN}-\mathrm{Chl}, \mathrm{CN}-\mathrm{Aqu}$, and CN-Crd inhibited MCF 10A cell growth with $\mathrm{IC}_{50}$ values of $40.43 \pm 1.70 \mu \mathrm{g} / \mathrm{mL}, 57.55 \pm 0.38 \mu \mathrm{g} / \mathrm{mL}$, $160.40 \pm 0.52 \mu \mathrm{g} / \mathrm{mL}$, and $53.15 \pm 0.23 \mu \mathrm{g} / \mathrm{mL}$, respectively, and had lower SI values than the CN-Dcm fraction. These results suggest that these fractions were more toxic to the normal cells than to the cancer cells. The growth of MCF $10 \mathrm{~A}$ cells exposed to CN-But was inhibited at an $\mathrm{IC}_{50}$ value of 
$86.50 \pm 1.06 \mu \mathrm{g} / \mathrm{mL}$, whereas it inhibited the growth of MCF7 cancer cells with an $\mathrm{IC}_{50}$ value of 111.50 $\pm 0.20 \mu \mathrm{g} / \mathrm{mL}$. Thus, the CN-But fraction had selective toxicity to the cancer cells, unlike CN-Hex, $\mathrm{CN}-\mathrm{Chl}, \mathrm{CN}-\mathrm{Aqu}$, and $\mathrm{CN}-\mathrm{Crd}$, which non-selectively inhibited the proliferation of both MCF7 and MCF 10A cells.

(a)

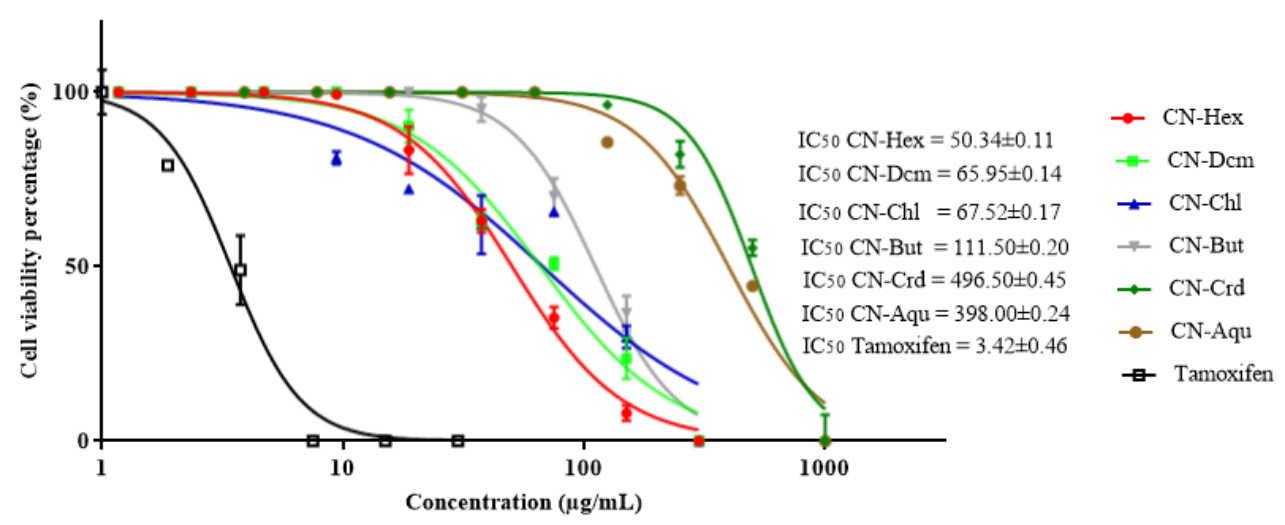

(b)

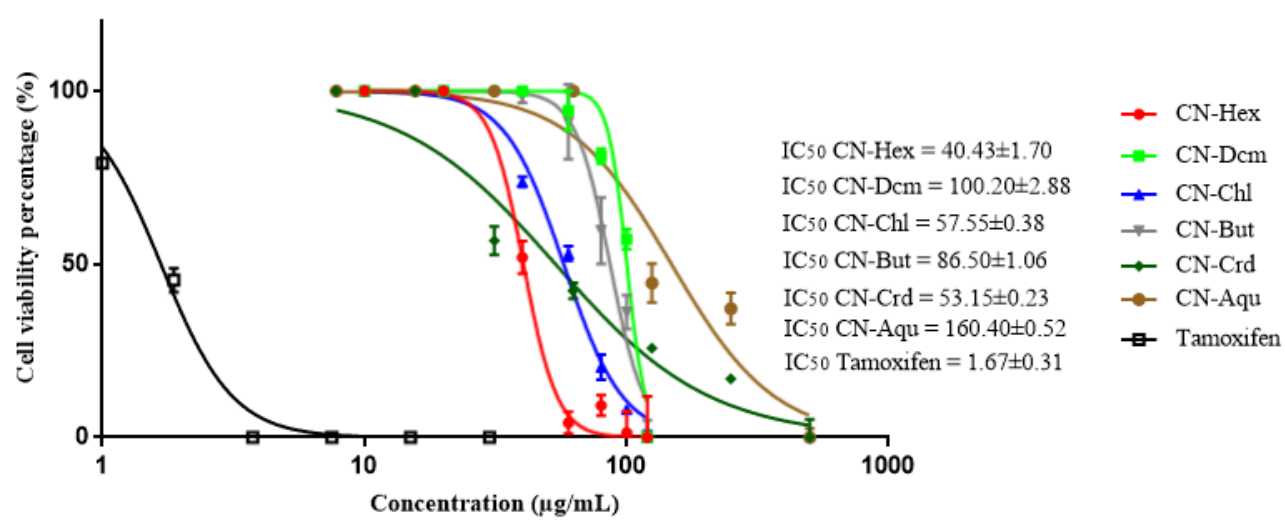

(c)

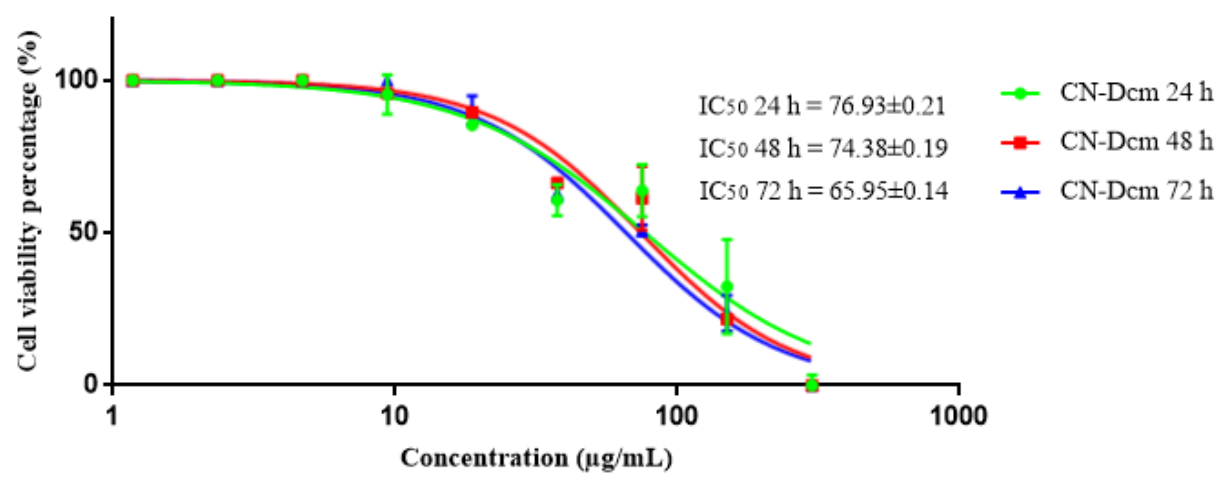

Figure 2. Preliminary screening of the $\mathrm{IC}_{50}$ of $C$. nutans crude and fraction extracts using the sulforhodamine B (SRB) assay: (a) antiproliferative effect of $C$. nutans extracts on MCF7 cell viability; (b) antiproliferative effect of $C$. nutans extracts on MCF 10A cells; (c) antiproliferative of the CN-Dcm fraction extract on MCF7 cells at 24, 48, and $72 \mathrm{~h}$ of exposure. Results are presented as mean \pm standard deviation (SD) ( $n=3$ ). CN-Crd, crude methanolic extract; CN-Hex, hexane fraction extract; CN-Dcm, dichloromethane fraction extract; $\mathrm{CN}-\mathrm{Chl}$, chloroform fraction extract; $\mathrm{CN}$-But, $n$-butanol fraction extract; $\mathrm{CN}-\mathrm{Aqu}$, aqueous residue fraction extract. 
Table 3. Selective index of crude and fraction extracts of $C$. nutans leaf activities.

\begin{tabular}{cc}
\hline Selective Index & MCF 10A/MCF7 \\
\hline CN-Crd & 0.11 \\
CN-Hex & 0.80 \\
CN-Dcm & 1.48 \\
CN-Chl & 0.85 \\
CN-But & 0.78 \\
CN-Aqu & 0.4 \\
Tamoxifen & 0.49 \\
\hline
\end{tabular}

$\mathrm{CN}-\mathrm{Crd}$, crude methanolic extract; CN-Hex, hexane fraction extract; $\mathrm{CN}-\mathrm{Dcm}$, dichloromethane fraction extract; $\mathrm{CN}$-Chl, chloroform fraction extract; $\mathrm{CN}$-But, $n$-butanol fraction extract; $\mathrm{CN}-\mathrm{Aqu}$, aqueous residue fraction extract.

Based on these results, CN-Dcm was the most selective fraction, as it selectively inhibited MCF7 cells and was less toxic to MCF 10A cells. Therefore, it was selected for further investigation. The results were in agreement with previous $C$. nutans studies, in which non-polar to semipolar extracts had higher antiproliferative activity than polar extracts [35,41-43]. However, none of the crude and fraction extracts of $C$. nutans leaves followed the criteria of the National Cancer Institute, which requires a crude plant extract to have an $\mathrm{IC}_{50}<30 \mu \mathrm{g} / \mathrm{mL}$ for preliminary assay [44]. The cell viability assay was repeated using the $\mathrm{CN}-\mathrm{Dcm}$ fraction extract for different incubation times $(24,48$, and $72 \mathrm{~h})$. The $\mathrm{IC}_{50}$ values for the three time points were plotted (Figure 2c) and show that at $24 \mathrm{~h}$ of treatment, CN-Dcm inhibited $50 \%$ of cell proliferation at a concentration of $76.93 \pm 0.21 \mu \mathrm{g} / \mathrm{mL}$, while at $48 \mathrm{~h}$ the $\mathrm{IC}_{50}$ of the extract was $74.38 \pm 0.19 \mu \mathrm{g} / \mathrm{mL}$ and at $72 \mathrm{~h}$ it was $65.95 \pm 0.14 \mu \mathrm{g} / \mathrm{mL}$. Thus, the inhibitory activity of this extract occurred in a dose- and time-dependent manner. The $\mathrm{IC}_{50}$ of the $\mathrm{CN}$-Dcm fraction decreased when the period of incubation increased.

\subsection{GC-MS Spectral Analysis of Compounds Presents in CN-Dcm}

We were able to separate and identify various constituents of CN-Dcm using GC-MS analysis. Table 4 summarizes the 14 components identified in the $\mathrm{CN}$-Dcm fraction with their molecular formula, peak percentage, and similarity index. Compounds were identified by referring to the corresponding compound in the National Institute of Standards and Technology (NIST) library; a similarity index of at least $80 \%$ was required for identification. The GC-MS analysis revealed the presence of two major components: linolenyl alcohol (29.10\%) and palmitic acid (23.84\%).

Table 4. Results of the GC-MS analysis of the CN-Dcm fraction of the extract.

\begin{tabular}{|c|c|c|c|c|c|}
\hline Peak & Compound & $\begin{array}{l}\text { Retention } \\
\text { Time }\end{array}$ & $\begin{array}{l}\text { Molecular } \\
\text { Formula }\end{array}$ & $\begin{array}{l}\text { Similarity } \\
\text { Index }\end{array}$ & $\begin{array}{c}\text { Peak } \\
\text { Percentage }(\%)\end{array}$ \\
\hline 1 & Methyl beta-D-glucopyranoside & 9.028 & $\mathrm{C}_{7} \mathrm{H}_{14} \mathrm{O}_{6}$ & 90 & 0.97 \\
\hline 2 & Methyl 4-hydroxycinnamate & 9.514 & $\mathrm{C}_{10} \mathrm{H}_{10} \mathrm{O}_{3}$ & 91 & 3.81 \\
\hline 3 & Methyl trans-3-hydroxycinnamate & 10.077 & $\mathrm{C}_{10} \mathrm{H}_{10} \mathrm{O}_{3}$ & 94 & 11.37 \\
\hline 4 & Methyl palmitate & 10.96 & $\mathrm{C}_{17} \mathrm{H}_{34} \mathrm{O}_{2}$ & 99 & 1.55 \\
\hline 5 & Palmitic acid & 11.133 & $\mathrm{C}_{16} \mathrm{H}_{32} \mathrm{O}_{2}$ & 99 & 23.84 \\
\hline 6 & $\begin{array}{l}\text { 10,13-Octadecadienoic acid, methyl } \\
\text { ester }\end{array}$ & 11.807 & $\mathrm{C}_{19} \mathrm{H}_{34} \mathrm{O}_{2}$ & 99 & 0.92 \\
\hline 7 & Methyl linolenate & 11.842 & $\mathrm{C}_{19} \mathrm{H}_{32} \mathrm{O}_{2}$ & 99 & 5.86 \\
\hline 8 & Phytol & 11.891 & $\mathrm{C}_{20} \mathrm{H}_{40} \mathrm{O}$ & 80 & 0.60 \\
\hline 9 & Methyl stearate & 11.926 & $\mathrm{C}_{19} \mathrm{H}_{38} \mathrm{O}_{2}$ & 99 & 0.53 \\
\hline 10 & Linolenyl alcohol & 12.023 & $\mathrm{C}_{18} \mathrm{H}_{32} \mathrm{O}$ & 95 & 29.10 \\
\hline 11 & Octadecanoic acid & 12.078 & $\mathrm{C}_{18} \mathrm{H}_{36} \mathrm{O}_{2}$ & 99 & 6.15 \\
\hline 12 & $\begin{array}{c}\text { 2-(((2-Ethylhexyl)oxy)carbonyl)benzoic } \\
\text { acid }\end{array}$ & 14.045 & $\mathrm{C}_{16} \mathrm{H}_{22} \mathrm{O}_{4}$ & 91 & 14.51 \\
\hline 13 & Glyceryl 2-linolenate & 15.053 & $\mathrm{C}_{21} \mathrm{H}_{36} \mathrm{O}_{4}$ & 99 & 0.44 \\
\hline 14 & Oleamide & 15.706 & $\mathrm{C}_{18} \mathrm{H}_{35} \mathrm{NO}$ & 90 & 0.34 \\
\hline
\end{tabular}




\subsection{Molecular Docking}

\subsubsection{Drug-Likeness and Toxicity Prediction}

The two major compounds found in the CN-Dcm fraction, palmitic acid and linolenyl alcohol (Figure 3), were subjected to drug-likeness and toxicity prediction using Lipinski's rule of five; this rule determines the consistency of orally active drugs [45]. Lipinski's rule of five [45] states that a drug molecule generally does not violate more than one of the following five rules: molecular mass $<500$ Da, high lipophilicity (expressed as LogP $<$ than 5), $<5$ hydrogen bond donors, $<10$ hydrogen bond acceptors, and molar refractivity between 40 and 130 [46,47]. As displayed in Table 5, linolenyl alcohol and palmitic acid did not violate any rules, suggesting that they could be suitable for oral administration.

(a)

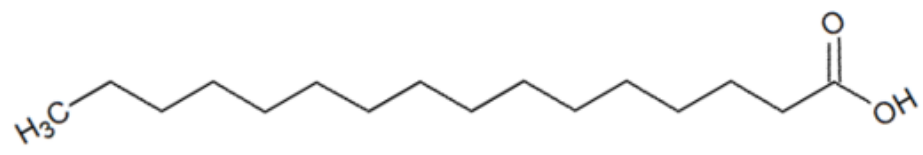

(b)

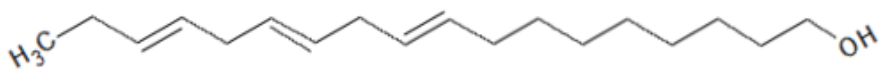

Figure 3. The major compounds found in $\mathrm{CN}-\mathrm{Dcm}$ fraction extract of $\mathrm{C}$. nutans leaves: (a) palmitic acid; (b) linolenyl alcohol.

Table 5. Lipinski's rule for major compounds of CN-Dcm, assessed by SwissADME web tool.

\begin{tabular}{ccccccc}
\hline Compound & $\begin{array}{c}\text { Molecular } \\
\text { Weight (Da) }\end{array}$ & $\begin{array}{c}\text { Hydrogen } \\
\text { Bond Donor }\end{array}$ & $\begin{array}{c}\text { Hydrogen Bond } \\
\text { Acceptor }\end{array}$ & LogP & $\begin{array}{c}\text { Molar } \\
\text { Refractivity }\end{array}$ & $\begin{array}{c}\text { Rules } \\
\text { Satisfied }\end{array}$ \\
\hline Palmitic acid & 256.42 & 1 & 2 & 4.19 & 80.80 & $5 / 5$ \\
Linolenyl alcohol & 264.45 & 1 & 1 & 4.59 & 88.38 & $5 / 5$ \\
\hline
\end{tabular}

\subsubsection{Molecular Docking Analysis}

Molecular docking analysis is widely used in drug discovery to understand the drug-receptor interaction and gene pathway [48]. The antiproliferative effect of the C. nutans extracts may be caused by activation of apoptosis proteins. Apoptosis, or programmed cell death, is an important component of regulation of cell growth and maintenance of tissue homeostasis, and it is restricted during uncontrolled growth of damaged cells [49]. Apoptosis is also the hallmark of cancer [50]. In this analysis, we studied the following apoptosis-related proteins: tumor necrosis factor- $\alpha$ (TNF- $\alpha$ ), p53-binding protein Mdm-2, and caspase-3. The p53 tumor suppressor protein activates transcription of proapoptotic genes that encode members of the Bcl-2 family, as well as TNF-related apoptosis [51]. Activation of p53 only occurs through its dissociation from its inhibitor, MDM2; thus, MDM2 inhibitors are considered to be proapoptotic agents [52,53]. Álvarez et al. [54] reported that the cytokinine TNF- $\alpha$ can promote activation of caspase- 3 by expresssing Fas ligand (FasL) through nuclear factor of activated T-cells (NFAT) activation in neuroblastoma cells. Caspase-3 is an essential marker that has been shown to be an entry point in the apoptotic signalling pathway. Hence, caspase-3 is important for the formation of apoptoic bodies and dismantling of the cells, and may function before or after the loss of cell viability [55].

In this study, the proteins TNF- $\alpha$, p53 binding protein Mdm-2, and caspase-3 were docked with palmitic acid and linolenyl alcohol. Table 6 shows the best result for each compound and the apoptosis proteins. Palmitic acid and linolenyl alcohol had the highest binding affinities towards p53-binding protein Mdm-2, with binding energy values of $-4.22 \mathrm{kcal} / \mathrm{mol}$ and $-4.56 \mathrm{kcal} / \mathrm{mol}$, respectively. According to Pantsar and Poso [56], the lowest binding energies of ligands towards the targeted 
proteins result in the highest binding affinities. The lowest binding affinities detected were -2.45 $\mathrm{kcal} / \mathrm{mol}$ and $-2.99 \mathrm{kcal} / \mathrm{mol}$ for palmitic acid and linolenyl alcohol with TNF- $\alpha$ protein, respectively.

Table 6. Binding energy of major compounds and apoptosis proteins. TNF- $\alpha$, tumor necrosis factor- $\alpha$.

\begin{tabular}{ccc}
\hline \multirow{2}{*}{ Proteins } & \multicolumn{2}{c}{ Binding Energy (kcal/mol) } \\
\cline { 2 - 3 } & Palmitic Acid & Linolenyl Alcohol \\
\hline TNF- $\alpha$ & -2.45 & -2.99 \\
p53-binding protein Mdm-2 & -4.22 & -4.56 \\
Caspase-3 & -3.56 & -3.93 \\
\hline
\end{tabular}

Protein docking analysis showed that linolenyl alcohol had better binding affinity towards p53-binding protein Mdm-2 compared to palmitic acid. Figure 4 shows results of the interaction pattern analysis of the compounds with apoptosis proteins. Based on the result from Discovery Studio Visualizer 4.1 client, the molecular interactions of linolenyl alcohol with p53-binding protein Mdm-2 formed two Pi-Alkyl interactions with Phe-55 and Tyr-56, two hydrogen bonds were formed, and two hydrophobic interactions occurred. Palmitic acid formed eight hydrogen bonds with four residues, namely Gln-59, Lys-24, Phe-55, and Tyr-56. Palmitic acid also formed two Pi-Alkyl interactions with Phe-55 and Tyr-56 residues. The finding demonstrated that caspase- 3 bound to palmitic acid and linolenyl alcohol, with binding energies of $-3.56 \mathrm{kcal} / \mathrm{mol}$ and $-3.93 \mathrm{kcal} / \mathrm{mol}$, respectively. Mutazah et al. [57] previously reported that entadamide C (1) and clinamide D (2) from C. nutans extracts bound favorably to the caspase- 3 binding site, with binding energies of $-4.28 \mathrm{kcal} / \mathrm{mol}$ and $-4.84 \mathrm{kcal} / \mathrm{mol}$, respectively. Thus, these results showed that such interactions of $C$. nutans compounds are important for the activation of apoptosis-related proteins.

(a) (i)

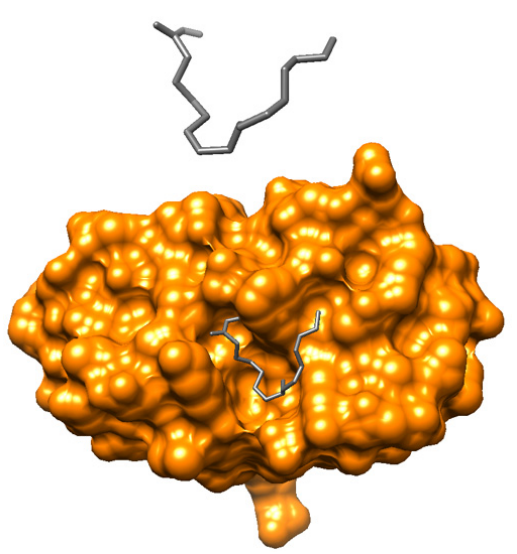

(b) (i)

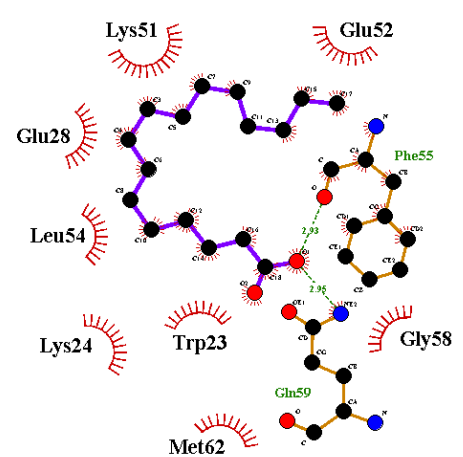

(ii)

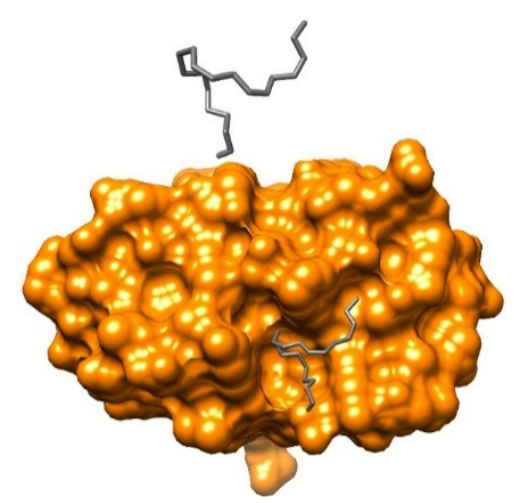

(ii)

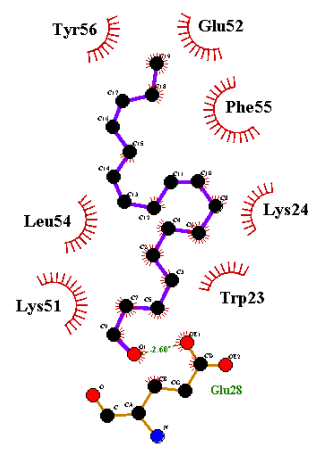

Figure 4. Cont. 
(c) (i)

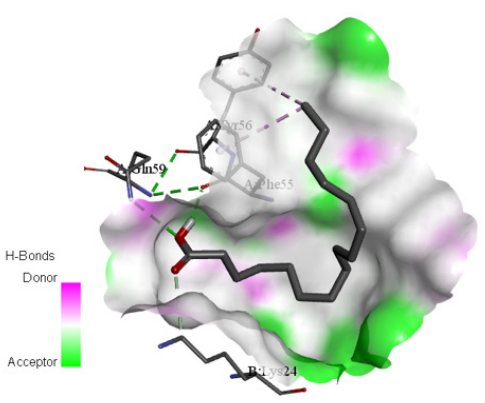

(ii)

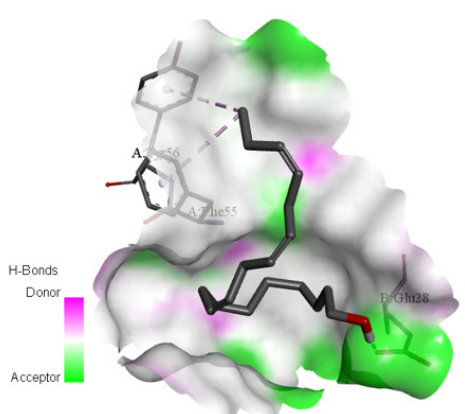

Figure 4. Molecular docking and interaction pattern analysis of the compounds with apoptosis proteins: (a) the best binding affinities of the compounds with targeted proteins; (b) interaction of the compounds and active site residues using LigPlot+; (c) interaction of the compounds with active site residues using Discovery Studio Visualizer 4.1 client. The compounds and proteins correspond to (i) palmitic acid with p53-binding protein Mdm-2 and (ii) linolenyl alcohol with p53-binding protein Mdm-2.

\section{Materials and Methods}

\subsection{Reagents}

Analytical grade methanol, hexane, dichloromethane, chloroform, $n$-butanol, dimethylsulfoxide (DMSO), acetic acid, and HPLC-grade methanol were purchased from Qrec (Asia) Sdn. Bhd (Rawang, Selangor, Malaysia). Folin-Ciocalteu reagent, sodium carbonate, DPPH, ABTS, aluminum chloride, potassium persulfate, sulforhodamine $\mathrm{B}$, tris buffer, and trichloroacetic acid were purchased from Sigma-Aldrich (St. Louis, MO, USA). The standards for antioxidant assays (quercetin, gallic acid, and vitamin E analogue 6-hydroxy 2,5,7,8-tetramethylchroman-2-carboxylic acid (Trolox)) were purchased from Sigma-Aldrich (St. Louis, MO, USA). Roswell Park Memorial Institute culture medium (RPMI-1640) and fetal bovine serum were purchased from Nacalai Tesque (Kyoto, Japan). Dulbecco's modified Eagle medium (DMEM), penicillin-streptomycin (PenStrep), horse serum, epidermal growth factor (EGF), hydrocortisone, and insulin were purchased from Gibco (Paisley, UK). Trypan blue was purchased from Hycel de México (Zapopan, México).

\subsection{Plant Material and Sample Preparation}

Fresh samples of $C$. nutans were purchased from HERBagus at Kepala Batas, Penang, Malaysia $\left(5.5185^{\circ} \mathrm{N}, 100.4799^{\circ} \mathrm{E}\right)$, and the plant was identified using DNA barcoding markers [9]. The leaves were separated from the plants and washed with distilled water. Fresh leaves ( $3000 \mathrm{~g})$ were ground and soaked with $80 \%$ methanol $(2.5 \mathrm{~L})$ at room temperature $\left(20^{\circ} \mathrm{C}\right)$. The mixtures were continuously shaken at $130 \mathrm{rpm}$ for $24 \mathrm{~h}$ on a shaker. The filtrate was collected by filtration of the mixtures through a Whatman No. 1 filter paper by gravity. The extraction was repeated two more times and the crude extracts were pooled together. Methanol was evaporated from the pooled crude extract using a rotary evaporator $\left(125 \mathrm{hpa}, 40^{\circ} \mathrm{C}\right)$ and the crude extract was freeze-dried.

Next, $70 \mathrm{~g}$ of crude extract were dissolved with distilled water $(100 \mathrm{~mL})$ and subjected to liquid-liquid fractionation with each of the following four solvents $(200 \mathrm{~mL})$ of different polarities: $n$-hexane (CN-Hex), dichloromethane ( $\mathrm{Cn}$-Dcm), chloroform (CN-Chl), and n-butanol (CN-But) (Figure 5). The mixtures were mixed vigorously with the solvents $(200 \mathrm{~mL})$ in a separatory funnel for $30 \mathrm{~min}$. The extraction solvents were evaporated from the fractions, and water was also evaporated. All samples were kept at $4{ }^{\circ} \mathrm{C}$ until further use. 


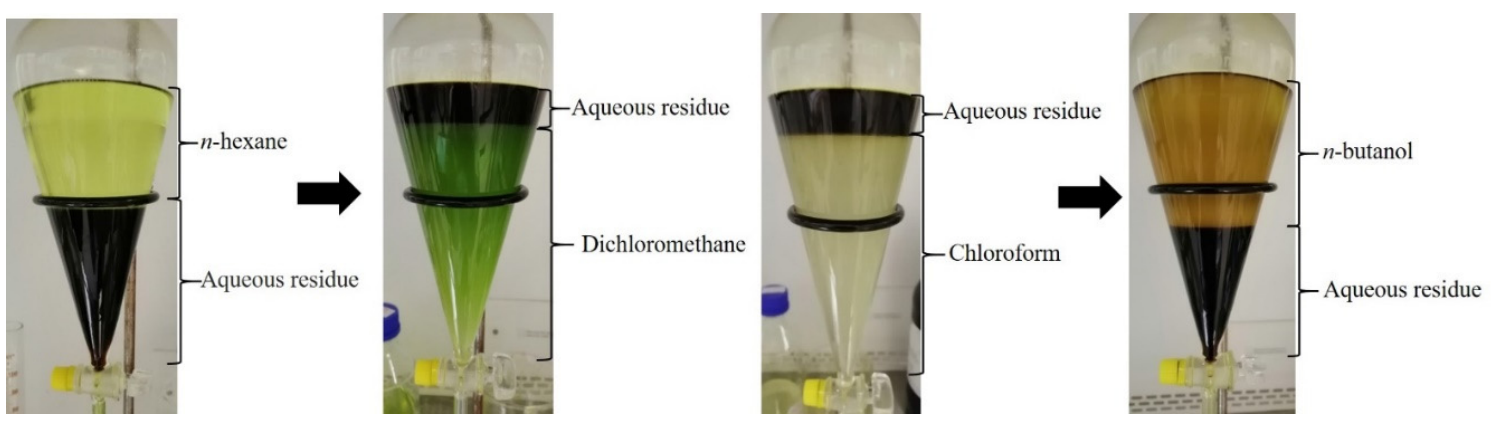

Figure 5. Fractionation of crude extracts using four solvents of different polarities ( $n$-hexane, dichloromethane, chloroform, and n-butanol, along with aqueous residue).

\subsection{Determination of Antioxidant Activities}

\subsubsection{TPC}

The TPC of C. nutans crude and fraction extracts was measured following Ismail et al. [28], with slight modification. First, $1000 \mu \mathrm{g}$ of each extract were diluted using $50 \%$ methanol to obtain $1000 \mu \mathrm{g} / \mathrm{mL}$ of sample concentration and then $1 \mathrm{~mL}$ of $100 \%$ Folin-Ciocalteu reagent was mixed with $9 \mathrm{~mL}$ of distilled water. Next, $0.3 \mathrm{~g}$ of sodium carbonate was dissolved in $4 \mathrm{~mL}$ of distilled water to obtain $7.5 \%$ sodium carbonate. The extracts $(20 \mu \mathrm{L})$ were added to $96-$ well plates and mixed with $100 \mu \mathrm{L}$ of $10 \%$ Folin-Ciocalteu reagent. The mixtures were incubated for $5 \mathrm{~min}$ in the dark. Next, $80 \mu \mathrm{L}$ of $7.5 \%$ sodium carbonate were added to the mixtures, which were incubated for $30 \mathrm{~min}$ before reading the absorbance at $760 \mathrm{~nm}$ using a spectrophotometer (OMEGA BMG Labtech, Ortenberg, Germany). The analysis was performed in triplicate. A total of nine concentrations of gallic acid ranging from 3.9 to $1000 \mu \mathrm{g} / \mathrm{mL}$ were made by serial dilution. The same procedure was repeated for the gallic acid concentrations and the calibration line was created. The TPC was expressed as percentage of total gallic acid equivalents per g extract (mg GAE/g). The TPC regression curve for the gallic acid standard had the equation $y=0.0076 x-0.0031$, with an $R^{2}$ value of 0.9999 .

\subsubsection{TFC}

The TFC of $C$. nutans crude and fraction extracts was measured following Ismail et al. [28]. A $100 \mu \mathrm{L}$ aliquot of the prepared solutions $(1000 \mu \mathrm{g} / \mathrm{mL})$ of crude and fraction extracts of $C$. nutans leaves was added to $100 \mu \mathrm{L}$ of $2 \%$ aluminum chloride and incubated for $10 \mathrm{~min}$ in the dark. The absorbance of the mixture then was read using a spectrophotometer at $420 \mathrm{~nm}$. The analysis was performed in triplicate. Serial dilutions of the standard quercetin starting from $1000 \mu \mathrm{g} / \mathrm{mL}$ were used to generate a standard curve. The TFC was expressed as percentage of total quercetin equivalents per g extract ( $\mathrm{mg}$ $\mathrm{QE} / \mathrm{g}$ ). The TFC regression curve for the quercetin standard had the equation $\mathrm{y}=0.0107 \mathrm{x}+0.0272$, with an $\mathrm{R}^{2}$ value of 0.9989 .

\subsubsection{DPPH}

The antioxidant capacity was measured using the DPPH radical scavenging method, as described by Ismail et al. [28], with some modifications. A $0.6 \mathrm{mM} \mathrm{DPPH} \mathrm{stock} \mathrm{solution} \mathrm{was} \mathrm{prepared} \mathrm{by} \mathrm{dissolving}$ $6 \mathrm{mg}$ of DPPH in $25 \mathrm{~mL}$ of methanol. The DPPH working solution was obtained by dissolving the DPPH stock solution in methanol until the absorbance reading at $517 \mathrm{~nm}$ was $1.1 \pm 0.02 \mathrm{~nm}$. Next, $50 \mu \mathrm{L}$ of the $C$. nutans crude and fraction extracts ranging from concentrations of 125 to $4000 \mu \mathrm{g} / \mathrm{mL}$ were added to $100 \mu \mathrm{L}$ of DPPH working solution in 96-well plates. The mixtures were incubated at $30 \mathrm{~min}$ in the dark. The absorbance was read at $517 \mathrm{~nm}$ using the spectrophotometer. Trolox ranging from 3.9 to $1000 \mu \mathrm{g} / \mathrm{mL}$ was used as a positive control. The experiment was performed in triplicate for the standard and the extracts. The inhibition ratio was calculated as percentage of inhibition using the following formula: percentage inhibition $(\%)=(($ absorbance of control $)-($ absorbance of test 
sample)/absorbance of control) $\times 100 \%$. The extract concentration providing the half-maximal effective concentration $\left(\mathrm{EC}_{50}\right)$ was calculated using a graph by plotting the percentage effective concentration against extract concentration. The data were presented as mean values \pm standard deviation (SD).

\subsubsection{ABTS}

The ABTS radical cation decolorization assay described by Fidrianny et al. [58] was used. The ABTS radical cation working solution was produced by reacting $7.5 \mathrm{mM}$ ABTS stock solution with $3.8 \mathrm{mM}$ potassium persulfate, and the mixture was allowed to stand in the dark at room temperature for $16 \mathrm{~h}$ before use to yield a dark-colored solution containing ABTS $\bullet+$ radicals. The ABTS radical cation working solution was then diluted with methanol for an initial absorbance of about $0.70 \pm 0.02$ at $734 \mathrm{~nm}$. Mixtures in a total volume of $100 \mu \mathrm{L}$ containing $90 \mu \mathrm{L}$ of ABTS radical cation working solution and $10 \mu \mathrm{L}$ of varying concentrations of the extract $(125-4000 \mu \mathrm{g} / \mathrm{mL})$ were incubated in the dark. Appropriate solvent blanks were run with each assay. The absorbance was read by the spectrophotometer at $734 \mathrm{~nm}$ and compared with the Trolox control $(3.9-1000 \mu \mathrm{g} / \mathrm{mL})$. The assay was performed in triplicate. The scavenging activity was estimated based on the $\mathrm{EC}_{50}$ of ABTS radicals scavenged. The data were presented as mean values $\pm \mathrm{SD}$.

\subsubsection{Statistical Analysis}

All the experiments for determination of TPC, TFC, and antioxidant properties using DPPH and ABTS were conducted in triplicates. The values are expressed as the mean \pm standard deviation (SD). The statistical analysis of the results was done by IBM Statistical Package for Social Sciences (SPSS) Statistical Version 24 for statistical computing. Analysis of variance (ANOVA) and significance of differences among means were tested by one-way ANOVA and least significant difference (LSD) on mean values, respectively.

\subsection{Cell Culture for Cytotoxicity Testing}

Cryovials containing MCF7 and MCF 10A cells were thawed in a water bath at $37^{\circ} \mathrm{C}$. The cells were then transferred into a $15 \mathrm{~mL}$ centrifuge tube and centrifuged at $1000 \mathrm{rpm}$ for $5 \mathrm{~min}$ to remove the cryopreservative agent (DMSO). The MCF7 cells were introduced into a T-25 falcon flask and cultivated in RPMI-1640 medium supplemented with 10\% (v/v) fetal bovine serum and 1\% PenStrep to increase and stimulate cells survival and proliferation. PenStrep was added to preferentially kill any bacteria present that might contaminate the cells. The MCF 10A were cultivated in DMEM supplemented with $5 \%$ horse serum, $20 \mathrm{mg} / \mathrm{mL}$ epidermal growth factor, $0.5 \mathrm{mg} / \mathrm{mL}$ hydrocortisone, $10 \mu \mathrm{g} / \mathrm{mL}$ insulin, and $5 \mathrm{~mL}$ of PenStrep. Both cell types were incubated at $37^{\circ} \mathrm{C}$ in a $\mathrm{CO}_{2}$ incubator supplemented with $5 \% \mathrm{CO}_{2}$. The media were replaced every 3 days until the cells were confluent and ready to be sub-cultivated. The medium in each flask was discarded when the cells reached confluence. The cells were then washed two times with $2 \mathrm{~mL}$ of phosphate-buffered saline to ensure removal of any residue of spent culture medium and dead cells. Cells were detached by adding $200 \mu \mathrm{L}$ of trypsin and incubated for $5 \mathrm{~min}$. The process of trypsinization was enhanced by gently tapping the flask a few times. Once the cells appeared rounded and single under the microscope, $4 \mathrm{~mL}$ of medium were added to the cells to inactivate the trypsin. The cell suspension was transferred to a $15 \mathrm{~mL}$ falcon tube and centrifuged at $1000 \mathrm{rpm}$ for $5 \mathrm{~min}$. Cells then were resuspended in the culture media.

\subsubsection{Cell Viability Assay}

The effects of $C$. nutans crude extract and its fractions on the viability of MCF7 and MCF 10A cells were determined using the sulforhodamine B (SRB) assay, as described by Skehan et al. [34], with some modifications. Concentrations of MCF7 and MCF 10A cells growing in the exponential phase $\left(1 \times 10^{4}\right.$ cells $\left./ \mathrm{mL}\right)$ were produced using an automated cell counter. Aliquots of $100 \mu \mathrm{L}$ of medium were seeded into each well of 96-well plates and incubated in a $\mathrm{CO}_{2}$ incubator for $24 \mathrm{~h}$. The $\mathrm{CN}-\mathrm{Crd}$ extract and $\mathrm{CN}-\mathrm{Aqu}$ residue extract were dissolved in both complete media, whereas $\mathrm{CN}-\mathrm{Hex}, \mathrm{CN}-\mathrm{Dcm}$, 
$\mathrm{CN}-\mathrm{Chl}$, and CN-But fractions were dissolved in DMSO. The working solutions of fraction extracts were in $0.1 \%$ DMSO. This was to make sure that the highest DMSO concentration in the cell culture was within the acceptable limit $(0.1-0.5 \%)$ [59]. Briefly, the cells were incubated in 96-well plates with a serial dilution of extracts, starting with $1000 \mu \mathrm{g} / \mathrm{mL}$ (CN-Crd and CN-Aqu) and $300 \mu \mathrm{g} / \mathrm{mL}$ (CN-Hex, $\mathrm{CN}-\mathrm{Dcm}, \mathrm{CN}-\mathrm{Chl}$, and CN-But fraction extracts) for $72 \mathrm{~h}$ at $37^{\circ} \mathrm{C}$ with $5 \% \mathrm{CO}_{2}$.

For MCF 10A cells, the new range of crude and fraction extracts of $C$. nutans leaves was made based on the half-maximal inhibitory concentration $\left(\mathrm{IC}_{50}\right)$ of $\mathrm{MCF} 7$ cancer cells. The new range for MCF 10A cells started with $500 \mu \mathrm{g} / \mathrm{mL}$ (CN-Crd and CN-Aqu) and $120 \mu \mathrm{g} / \mathrm{mL}$ (CN-Hex, CN-Dcm, $\mathrm{CN}-\mathrm{Chl}$, and $\mathrm{CN}$-But fraction extracts). The positive control experiment involved tamoxifen, and the negative control was untreated media or $0.1 \%$ DMSO. At the end of the incubation period, the cells were fixed with $50 \mu \mathrm{L}$ of $50 \%$ cold trichloroacetic acid for $30 \mathrm{~min}$ at room temperature, followed by gentle tap water washing (4x) and drying. The cells then were then stained with $100 \mu \mathrm{L}$ of $0.4 \%$ SRB in $1 \%$ acetic acid for $30 \mathrm{~min}$, followed by washing with $1 \%$ acetic acid (4x). The plate was dried, $100 \mu \mathrm{L}$ of $10 \mathrm{mM}$ Tris buffer were added to each well, and the plate was shaken for $5 \mathrm{~min}$. Relative cell viability was measured by scanning at $570 \mathrm{~nm}$ on a microplate reader (OMEGA BMG Labtech, Subang Jaya, Selangor, Malaysia). The cytotoxicity was determined using the previously described formula reported by Bendale et al. [60]:

$$
\text { Cytotoxicity }(\%)=\text { Optical density of (sample }- \text { blank)/Optical density of }(\text { control }- \text { blank }) \times 100 \%
$$

\subsubsection{Selective Index (SI)}

The SI was used to determine the cytotoxic selectivity of the substances tested. It was calculated according to the following equation [61]:

$$
\mathrm{SI}=\mathrm{IC}_{50} \text { (normal cells)/ } / \mathrm{IC}_{50} \text { (cancer cells) }
$$

The extract with highest SI CN-Dcm) was selected for another cell viability assay at different incubation times $(24,48$, and $72 \mathrm{~h})$.

\subsection{GC-MS}

For the GC-MS analysis, $1000 \mu \mathrm{g} / \mathrm{mL}$ of CN-Dcm was dissolved in $1 \mathrm{~mL}$ of HPLC grade methanol. The secondary metabolites from CN-Dcm were determined using an Agilent gas chromatograph model 6890 equipped with an Agilent 19091S-433 capillary column, (5\%-phenyl)-methylpolysiloxane phase (HP-5MS) $0.25 \mathrm{~mm} \times 30 \mathrm{~m} \times 0.25 \mu \mathrm{m}$ ) (Santa Clara, CA, USA). Helium gas was used as the carrier gas at $1.0 \mathrm{~mL}$ per minute with split mode injection. The oven temperature was set as follows: $70^{\circ} \mathrm{C}$ was held for $2 \mathrm{~min}$, then it was increased to $280^{\circ} \mathrm{C}$ at a rate of $20^{\circ} \mathrm{C}$ per min for $20 \mathrm{~min}$. The total run time was $32.50 \mathrm{~min}$.

\subsection{Molecular Docking}

\subsubsection{Drug-Likeness and Toxicity Predictions}

Lipinski's rule of five was used to predict the drug-likeness; this rule determines the consistency of orally active drugs [45,47]. In this study, the selected compounds (palmitic acid linolenyl alcohol) were screened using the SwissADME web tool predictor [62]. The SwissADME predictor provides data on the numbers of hydrogen acceptors, hydrogen donors, and rotatable bonds.

\subsubsection{Protein Model and Compound Structure}

Protein structures of tumor necrosis factor alpha (TNF- $\alpha$, PDB ID: 2AZ5), p53-binding protein Mdm-2 (PDB ID: 1YCR), and caspase-3 (PDB ID: 6CKZ) were retrieved from the Research Collaboratory Structural Bioinformatics Protein Data Bank. All data files were saved in .pdb file format. Water and 
ligand molecules from the proteins were removed using Discovery Studio Visualizer 4.1 client [63]. The selected compounds (palmitic acid linolenyl alcohol) were structured using Advanced Chemistry Development/ChemSketch (ACD/ChemSketch) freeware [64]. The generated structures were saved in .mol2 file format, which then was converted to .pdb file format using Open Babel: The Open Source Chemistry Toolbox.

\subsubsection{Molecular Docking Analysis}

Molecular docking analysis was conducted using the automated docking tool AutoDock 4.2 [65]. Polar hydrogen atoms and Gasteiger partial charges were added to the three-dimensional protein structure. The protein structure was written in .pdbqt file format for further analysis. In this study, the grid size was set at $40 \times 40 \times 40$ points, with $0.375 \AA$ spacing centered on TNF- $\alpha$, with grid centers $x$ (-13.687), y (71.607), and z (27.002); $40 \times 40 \times 40$ points with $0.375 \AA$ spacing centered on p53-binding protein Mdm-2, with grid centers x (22.407), y (-17.053), and z (-7.329); and $40 \times$ $40 \times 40$ points with $0.375 \AA$ spacing centered on caspase-3, with grid centers x (27.543), y (22.594), and $\mathrm{z}$ (37.217). Lamarckian Genetic Algorithm 4.2 was used in the docking analysis [66] and the protein macromolecules were kept rigid throughout the docking simulation. Genetic algorithm runs were set at 100 and the other parameters for docking analyses were left at default settings. The best protein-compound conformations were chosen from the AutoDock 4.2 scoring function, and they were ranked according to their binding affinities. Discovery Studio Visualizer 4.1 client [63], Chimera 1.14 [67], and LigPlot [68] were used for post-docking analyses.

\section{Conclusions}

The TPC, TFC, antioxidant scavenging activity, antiproliferative activities, and molecular docking of $C$. nutans leaf extracts were determined in this study. The TPC of C. nutans leaf extracts was higher than that of TFC. In addition, the CN-Hex fraction had the lowest antioxidant activity and the CN-Crd fraction had the highest antioxidant activity based on the $\mathrm{EC}_{50}$ value. The $\mathrm{CN}-\mathrm{Dcm}$ extract was chosen to study the antiproliferative effect of the leaf extract because it inhibited MCF7 cell growth and was less toxic towards MCF 10A cells. Molecular docking results showed that palmitic acid and linolenyl alcohol from the $\mathrm{CN}-\mathrm{Dcm}$ fraction could bind with three selected apoptosis-related proteins, and that p53-binding protein Mdm-2 had the highest binding affinity with both compounds. These results suggest that $\mathrm{CN}-\mathrm{Dcm}$ would be useful for identifying the compounds that best inhibit proliferation of cancer cells and in other applications for determining the apoptosis signaling pathway. For future studies, we would like to isolate and purify the potential active compounds from CN-Dcm fractions. Moreover, it would be worthwhile if we investigated the active compound activity against apoptosis analysis using RNA and protein expression.

Supplementary Materials: The following are available online: Table S1: The $\mathrm{IC}_{50}$ of $C$. nutans extracts using sulforhodamine B (SRB), 3-(4,5-dimethylthiazol-2-yl)-5-(3-carboxymethoxyphenyl)-2-(4-sulfophenyl)$2 \mathrm{H}$-tetrazolium (MTS), and alamar blue assays at $72 \mathrm{~h}$ exposure. The antiproliferative effects were evaluated by using MCF7 and MCF 10A.

Author Contributions: Conceptualization, N.Z.I. and H.A.; data curation, N.Z.I. and H.A.; formal analysis, N.Z.I. and Z.M.T.; funding acquisition, H.A.; investigation, N.Z.I.; methodology, N.Z.I., Z.M.T., and M.M.; project administration, M.M. and H.A.; resources, N.N.S.N.M.K. and N.N.M.Z.; software, N.Z.I.; supervision, N.N.M.Z. and H.A.; validation, N.Z.I., Z.M.T., M.M., and H.A.; visualization, N.Z.I.; writing-original draft, N.Z.I.; writing-review and editing, N.Z.I. and H.A. All authors have read and agreed to the published version of the manuscript.

Funding: This research was funded by Universiti Sains Malaysia Bridging Grant, grant number 304/CIPPT/6316239.

Acknowledgments: The first author gratefully acknowledges Universiti Sains Malaysia (USM) for fellowship under the USM Fellowship Scheme.

Conflicts of Interest: The authors declare no conflict of interest. 


\section{References}

1. El-Saied, F.; El-Aarag, B.; Salem, T.; Said, G.; Khalifa, S.A.; El-Seedi, H.R. Synthesis, characterization, and in vivo anti-cancer activity of new metal complexes derived from isatin-N (4) antipyrinethiosemicarbazone ligand against ehrlich ascites carcinoma cells. Molecules 2019, 24, 3313. [CrossRef] [PubMed]

2. Reed, J.C. Dysregulation of apoptosis in cancer. J. Clin. Oncol. 1999, 17, 2941. [CrossRef] [PubMed]

3. Ferlay, J.; Soerjomataram, I.; Dikshit, R.; Eser, S.; Mathers, C.; Rebelo, M.; Parkin, D.M.; Forman, D.; Bray, F. Cancer incidence and mortality worldwide: Sources, methods and major patterns in GLOBOCAN 2012. Int. J. Cancer 2015, 136, 359-386. [CrossRef] [PubMed]

4. Hisham, A.N.; Yip, C.H. Overview of breast cancer in Malaysian women: A problem with late diagnosis. Asian J. Surg. 2004, 27, 130-133. [CrossRef]

5. Sak, K. Chemotherapy and dietary phytochemical agents. Chemother. Res. Pract. 2012, 2012, 1-11. [CrossRef]

6. Siddiqui, M.; Rajkumar, S.V. The high cost of cancer drugs and what we can do about it. Mayo Clin. Proc. 2012, 87, 935-943. [CrossRef]

7. Yeo, B.S.; Yap, Y.J.; Koh, R.Y.; Ng, K.Y.; Chye, S.M. Medicinal properties of Clinacanthus nutans: A review. Trop. J. Pharm. Res. 2018, 17, 375-382. [CrossRef]

8. Chelyn, J.L.; Omar, M.H.; Yousof, M.; Akmal, N.S.; Ranggasamy, R.; Wasiman, M.I.; Ismail, Z. Analysis of flavone C-glycosides in the leaves of Clinacanthus nutans (Burm. f.) Lindau by HPTLC and HPLC-UV/DAD. Sci. World J. 2014, 2014, 1-7. [CrossRef]

9. Ismail, N.Z.; Arsad, H.; Samian, M.R.; Hamdan, M.R.; Othman, A.S. Assessment of three plastid DNA barcode markers for identification of Clinacanthus nutans (Acanthaceae). 3 Biotech 2018, 8, 1-8. [CrossRef]

10. Alam, A.; Ferdosh, S.; Ghafoor, K.; Hakim, A.; Juraimi, A.S.; Khatib, A.; Sarker, Z.I. Clinacanthus nutans: A review of the medicinal uses, pharmacology and phytochemistry. Asian Pac. J. Trop. Biomed. 2016, 9, 402-409. [CrossRef]

11. Levenson, A.S.; Jordan, V.C. MCF-7: The first hormone-responsive breast cancer cell line. Cancer Res. 1997, 57, 3071-3078.

12. Holliday, D.L.; Speirs, V. Choosing the right cell line for breast cancer research. Breast Cancer Res. 2011, 13, 1-7. [CrossRef] [PubMed]

13. Christgen, M.; Lehmann, U. MDA-MB-435: The questionable use of a melanoma cell line as a model for human breast cancer is ongoing. Cancer Biol. Ther. 2007, 6, 1351-1353. [CrossRef] [PubMed]

14. Robertson, J.F.; Osborne, C.K.; Howell, A.; Jones, S.E.; Mauriac, L.; Ellis, M.; Kleeberg, U.R.; Come, S.E.; Vergote, I.; Gertler, S.; et al. Fulvestrant versus anastrozole for the treatment of advanced breast carcinoma in postmenopausal women: A prospective combined analysis of two multicenter trials. Cancer 2003, 98, 229-238. [CrossRef] [PubMed]

15. Majeed, M.; Hussain, A.I.; Chatha, S.A.; Khosa, M.K.; Kamal, G.M.; Kamal, M.A.; Zhang, X.; Liu, M. Optimization protocol for the extraction of antioxidant components from Origanum vulgare leaves using response surface methodology. Saudi J. Biol. Sci. 2016, 23, 389-396. [CrossRef]

16. Dai, J.; Mumper, R.J. Plant phenolics: Extraction, analysis and their antioxidant and anticancer properties. Molecules 2010, 15, 7313-7352. [CrossRef]

17. Haron, N.H.; Abas, R.; Md Toha, Z.; Hamdam, M.R.; Azman, N.; Samian, M.R.; Arsad, H. Effect of different solvent extracts on phenolic, flavonoid and antioxidant content and antiproliferative activity of Clinacanthus nutans leaves extract. In Proceedings of the 41st Annual Conference of the Malaysian Society for Biochemistry and Molecular Biology, Pullman Kuala Lumpur Bangsar Hotel, Bangsar, Kuala Lumpur, Malaysia, 18 August 2016.

18. Sarega, N.; Imam, M.U.; Ooi, D.J.; Chan, K.W.; Md Esa, N.; Zawawi, N.; Ismail, M. Phenolic rich extract from Clinacanthus nutans attenuates hyperlipidemia-associated oxidative stress in rats. Oxidative Med. Cell. Longev. 2016, 1-16. [CrossRef]

19. Aliyu, A.; Ibrahim, M.; Musa, A.; Bulus, T.; Oyewale, A. Phenolics content and antioxidant capacity of extracts and fractions of Vernonia blumeoides (Asteraceae). Int. J. Biol. Chem. 2011, 5, 352-359. [CrossRef]

20. Johari, M.A.; Khong, H.Y. Total phenolic content and antioxidant and antibacterial activities of Pereskia bleo. Adv. Pharm. Sci. 2019, 2019, 1-4. [CrossRef] 
21. Sakanaka, S.; Ishihara, Y. Comparison of antioxidant properties of persimmon vinegar and some other commercial vinegars in radical-scavenging assays and on lipid oxidation in tuna homogenates. Food Chem. 2008, 107, 739-744. [CrossRef]

22. Kumar, A.; Premoli, M.; Aria, F.; Bonini, S.A.; Maccarinelli, G.; Gianoncelli, A.; Memo, M.; Mastinu, A. Cannabimimetic plants: Are they new cannabinoidergic modulators? Planta 2019, 249, 1681-1694. [CrossRef] [PubMed]

23. Premoli, M.; Aria, F.; Bonini, S.A.; Maccarinelli, G.; Gianoncelli, A.; Della Pina, S.; Tambaro, S.; Memo, M.; Mastinu, A. Cannabidiol: Recent advances and new insights for neuropsychiatric disorders treatment. Life Sci. 2019, 224, 120-127. [CrossRef] [PubMed]

24. Suriyatem, R.; Auras, R.A.; Intipunya, P.; Rachtanapun, P. Predictive mathematical modeling for EC50 calculation of antioxidant activity and antibacterial ability of Thai bee products. J. Appl. Pharm. Sci. 2017, 7, 122-133. [CrossRef]

25. Lachman, J.; Orsák, M.; Hejtmánková, A.; Kovářová, E. Evaluation of antioxidant activity and total phenolics of selected Czech honeys. Lwt Food Sci. Technol. 2010, 43, 52-58. [CrossRef]

26. Olugbami, J.O.; Gbadegesin, M.A.; Odunola, O.A. In vitro free radical scavenging and antioxidant properties of ethanol extract of Terminalia glaucescens. Phcog. Res. 2015, 7, 49-56. [CrossRef]

27. Alam, M.A.; Zaidul, I.; Ghafoor, K.; Sahena, F.; Hakim, M.; Rafii, M.; Abir, H.; Bostanudin, M.; Perumal, V.; Khatib, A. In vitro antioxidant and, $\alpha$-glucosidase inhibitory activities and comprehensive metabolite profiling of methanol extract and its fractions from Clinacanthus nutans. Bmc Complement. Altern. Med. 2017, 17, 1-10. [CrossRef]

28. Ismail, N.Z.; Arsad, H.; Samian, M.R.; Hamdan, M.R. Determination of phenolic and flavonoid contents, antioxidant activities and GC-MS analysis of Clinacanthus nutans (Acanthaceae) in different locations. Agrivita J. Agric. Sci. 2017, 39, 335-344. [CrossRef]

29. Ismail, N.Z.; Arsad, H.; Samian, M.R.; Ab Majid, A.H.; Hamdan, M.R. Evaluation of genetic diversity of Clinacanthus nutans (Acanthaceaea) using RAPD, ISSR and RAMP markers. Physiol. Mol. Biol. Plants 2016, 22, 523-534. [CrossRef]

30. Kuete, V.; Karaosmanoğlu, O.; Sivas, H. Anticancer activities of African medicinal spices and vegetables. In Medicinal Spices and Vegetables from Africa; Academic Press: London, UK, 2017; pp. 271-297.

31. Aslantürk, Ö.S. Genotoxicity-A predictable risk to our actual world. In In Vitro Cytotoxicity and Cell Viability Assays: Principles, Advantages, and Disadvantages, 1st ed.; Larramendy, M., Soloneski, S., Eds.; IntechOpen: London, UK, 2018; Volume 3, pp. 1-19. [CrossRef]

32. Vajrabhaya, L.O.; Korsuwannawong, S. Cytotoxicity evaluation of Clinacanthus nutans through dimethylthiazol diphenyltetrazolium bromide and neutral red uptake assays. Eur. J. Dent. 2016, 10, 134-138. [CrossRef]

33. Van Tonder, A.; Joubert, A.M.; Cromarty, A.D. Limitations of the 3-(4, 5-dimethylthiazol-2-yl)-2, 5-diphenyl-2H-tetrazolium bromide (MTT) assay when compared to three commonly used cell enumeration assays. BMC Res. Notes 2015, 8, 1-10. [CrossRef]

34. Skehan, P.; Storeng, R.; Scudiero, D.; Monks, A.; McMahon, J.; Vistica, D.; Warren, J.T.; Bokesch, H.; Kenney, S.; Boyd, M.R. New colorimetric cytotoxicity assay for anticancer-drug screening. J. Natl. Cancer Inst. 1990, 82, 1107-1112. [CrossRef] [PubMed]

35. Arullappan, S.; Rajamanickam, P.; Thevar, N.; Kodimani, C.C. In vitro screening of cytotoxic, antimicrobial and antioxidant activities of Clinacanthus nutans (Acanthaceae) leaf extracts. Trop. J. Pharm. Res. 2014, 13, 1455-1461. [CrossRef]

36. Haron, N.H.; Md Toha, Z.; Abas, R.; Hamdan, M.R.; Azman, N.; Khairuddean, M.; Arsad, H. In vitro cytotoxic activity of Clinacanthus nutans leaf extracts against HeLa cells. Asian Pac. J. Cancer 2019, 20, 601-609. [CrossRef] [PubMed]

37. Adebayo, I.A.; Arsad, H.; Samian, M.R. Antiproliferative effect on breast cancer (MCF7) of Moringa oleifera seed extracts. Afr. J. Tradit. Complement. Altern. Med. 2017, 14, 282-287. [CrossRef] [PubMed]

38. Tagne, R.S.; Telefo, B.P.; Talla, E.; Nyemb, J.N.; Njina, S.N.; Asrar, M.; Mukhtar, F.; Kamdje, A.H.N.; Moundipa, P.F.; Farooq, A.D. Bio-guided fractionation of methanol extract of Ziziphus mauritiana Lam.(bark) and effect of the most active fraction on cancer cell lines. Asian Pac. J. Trop. Dis. 2015, 5, 307-312. [CrossRef] 
39. Wang, K.S.; Chan, C.K.; Hidayat, A.F.A.; Wong, Y.H.; Kadir, H.A. Clinacanthus nutans induced reactive oxygen species-dependent apoptosis and autophagy in HCT116 human colorectal cancer cells. Pharm. Mag. 2019, 15, 87-97. [CrossRef]

40. Segun, P.A.; Ogbole, O.O.; Ismail, F.M.; Nahar, L.; Evans, A.R.; Ajaiyeoba, E.O.; Sarker, S.D. Resveratrol derivatives from Commiphora africana (A. Rich.) Endl. display cytotoxicity and selectivity against several human cancer cell lines. Phytother. Res. 2019, 33, 159-166. [CrossRef]

41. Ng, P.Y.; Chye, S.M.; Ng, C.H.; Koh, R.Y.; Tiong, Y.L.; Pui, L.P.; Tan, Y.H.; Lim, C.S.Y.; Ng, K.Y. Clinacanthus nutans hexane extracts induce apoptosis through a caspase-dependent pathway in human cancer cell lines. Asian Pac. J. Cancer Prev. 2017, 18, 917-926. [CrossRef]

42. Sulaiman, I.S.C.; Basri, M.; Chan, K.W.; Ashari, S.E.; Masoumi, H.R.F.; Ismail, M. In vitro antioxidant, cytotoxic and phytochemical studies of Clinacanthus nutans Lindau leaf extracts. Afr. J. Pharm. Pharm. 2015, 9, 861-874. [CrossRef]

43. Yong, Y.K.; Tan, J.J.; Teh, S.S.; Mah, S.H.; Ee, G.C.L.; Chiong, H.S.; Ahmad, Z. Clinacanthus nutans extracts are antioxidant with antiproliferative effect on cultured human cancer cell lines. Evid. Based Complement. Altern. Med. 2013, 2013, 1-8. [CrossRef]

44. Fadeyi, S.A.; Fadeyi, O.O.; Adejumo, A.A.; Okoro, C.; Myles, E.L. In vitro anticancer screening of 24 locally used Nigerian medicinal plants. Bmc Complement. Altern. Med. 2013, 13, 1-10. [CrossRef] [PubMed]

45. Lipinski, C.A. Lead and drug-like compounds: The rule-of-five revolution. Drug Discov. Today Technol. 2004, 1, 337-341. [CrossRef] [PubMed]

46. Oduselu, G.O.; Ajani, O.O.; Ajamma, Y.U.; Brors, B.; Adebiyi, E. Homology modelling and molecular docking studies of selected substituted Benzo [d] imidazol-1-yl) methyl) benzimidamide scaffolds on Plasmodium falciparum adenylosuccinate lyase receptor. Bioinform. Biol. Insights 2019, 13, 1-10. [CrossRef] [PubMed]

47. Lipinski, C.A.; Lombardo, F.; Dominy, B.W.; Feeney, P.J. Experimental and computational approaches to estimate solubility and permeability in drug discovery and development settings. Adv. Drug Deliv. Rev. 1997, 23, 3-25. [CrossRef]

48. Sethi, A.; Joshi, K.; Sasikala, K.; Alvala, M. Molecular docking in modern drug discovery: Principles and recent applications. In Drug Discovery and Development-New Advances; IntechOpen: London, UK, 2019; pp. 1-22.

49. Elmore, S. Apoptosis: A review of programmed cell death. Toxicol. Pathol. 2007, 35, 495-516. [CrossRef]

50. Adebayo, I.A.; Balogun, W.G.; Arsad, H. Moringa oleifera: An apoptosis inducer in cancer cells. Trop. J. Pharm. Res. 2017, 16, 2289-2296. [CrossRef]

51. Amaral, J.D.; Xavier, J.M.; Steer, C.J.; Rodrigues, C.M. The role of p53 in apoptosis. Discov. Med. 2010, 9, 145-152.

52. Adebayo, I.A.; Arsad, H.; Samian, M.R. Methyl elaidate: A major compound of potential anticancer extract of Moringa oleifera seeds binds with bax and MDM2 (p53 inhibitor) in silico. Pharm. Mag. 2018, 14, 554-557. [CrossRef]

53. Leão, M.; Pereira, C.; Bisio, A.; Ciribilli, Y.; Paiva, A.M.; Machado, N.; Palmeira, A.; Fernandes, M.X.; Sousa, E.; Pinto, M. Discovery of a new small-molecule inhibitor of p53-MDM2 interaction using a yeast-based approach. Biochem. Pharm. 2013, 85, 1234-1245. [CrossRef]

54. Álvarez, S.; Blanco, A.; Fresno, M.; Muñoz-Fernández, M.Á. TNF- $\alpha$ contributes to caspase-3 independent apoptosis in neuroblastoma cells: Role of NFAT. PLoS ONE 2011, 6, 1-13. [CrossRef]

55. Porter, A.G.; Jänicke, R.U. Emerging roles of caspase-3 in apoptosis. Cell Death Differ. 1999, 6, 99-104. [CrossRef] [PubMed]

56. Pantsar, T.; Poso, A. Binding affinity via docking: Fact and fiction. Molecules 2018, 23, 1899. [CrossRef] [PubMed]

57. Mutazah, R.; Hamid, H.A.; Ramli, A.N.M.; Aluwi, M.F.F.M.; Yusoff, M.M. In vitro cytotoxicity of Clinacanthus nutans fractions on breast cancer cells and molecular docking study of sulphur containing compounds against caspase-3. Food Chem. Toxicol. 2019, 135, 1-9. [CrossRef] [PubMed]

58. Fidrianny, I.; Rahmiyani, I.; Wirasutisna, K.R. Antioxidant capacities from various leaves extracts of four varieties mangoes using DPPH, ABTS assays and correlation with total phenolic, flavonoid, carotenoid. Int. J. Pharm. Pharm. Sci. 2013, 5, 189-194. [CrossRef] 
59. Scambia, G.; Ranelletti, F.; Panici, P.B.; De Vincenzo, R.; Bonanno, G.; Ferrandina, G.; Piantelli, M.; Bussa, S.; Rumi, C.; Cianfriglia, M. Quercetin potentiates the effect of adriamycin in a multidrug-resistant MCF-7 human breast-cancer cell line: P-glycoprotein as a possible target. Cancer Chemother. Pharm. 1994, 34, 459-464. [CrossRef]

60. Bendale, Y.; Bendale, V.; Paul, S. Evaluation of cytotoxic activity of platinum nanoparticles against normal and cancer cells and its anticancer potential through induction of apoptosis. Integr. Med. Res. 2017, 6, 141-148. [CrossRef]

61. Peña-Morán, O.A.; Villarreal, M.L.; Álvarez-Berber, L.; Meneses-Acosta, A.; Rodríguez-López, V. Cytotoxicity, post-treatment recovery, and selectivity analysis of naturally occurring podophyllotoxins from Bursera fagaroides var. fagaroides on breast cancer cell lines. Molecules 2016, 21, 1013. [CrossRef]

62. Daina, A.; Michielin, O.; Zoete, V. SwissADME: A free web tool to evaluate pharmacokinetics, drug-likeness and medicinal chemistry friendliness of small molecules. Sci. Rep. 2017, 7, 1-13. [CrossRef]

63. Discovery Studio Visualizer V 19. Available online: https://www.3dsbiovia.com/products/collaborativescience/biovia-discovery-studio/visualization-download.php (accessed on 18 March 2019).

64. Hunter, A.D. ACD/ChemSketch 1.0 (freeware). Chem. Educ. Today 1997, 74, 905-906. [CrossRef]

65. Morris, G.M.; Huey, R.; Lindstrom, W.; Sanner, M.F.; Belew, R.K.; Goodsell, D.S.; Olson, A.J. AutoDock4 and AutoDockTools4: Automated docking with selective receptor flexibility. J. Comput. Chem. 2009, 30, 2785-2791. [CrossRef]

66. Morris, G.M.; Goodsell, D.S.; Halliday, R.S.; Huey, R.; Hart, W.E.; Belew, R.K.; Olson, A.J. Automated docking using a Lamarckian genetic algorithm and an empirical binding free energy function. J. Comput. Chem. 1998, 19, 1639-1662. [CrossRef]

67. Meng, E.C.; Pettersen, E.F.; Couch, G.S.; Huang, C.C.; Ferrin, T.E. Tools for integrated sequence-structure analysis with UCSF Chimera. BMC Bioinform. 2006, 7, 1-10. [CrossRef]

68. Wallace, A.C.; Laskowski, R.A.; Thornton, J.M. LIGPLOT: A program to generate schematic diagrams of protein-ligand interactions. Protein Eng. Des. Sel. 1995, 8, 127-134. [CrossRef] [PubMed]

Sample Availability: Samples of the compounds are available from the authors.

(C) 2020 by the authors. Licensee MDPI, Basel, Switzerland. This article is an open access article distributed under the terms and conditions of the Creative Commons Attribution (CC BY) license (http://creativecommons.org/licenses/by/4.0/). 